\title{
HOW DO PERSONALITY CHARACTERISTICS INFLUENCE RECOVERY AFTER STROKE? A LITERATURE REVIEW
}

\author{
Katarína Dančová, Jana Turzáková, Katarína Baňasová, Martina Romanová \\ Institute of Applied Psychology, Faculty of Social Sciences and Health Care, Constantine \\ the Philosopher University in Nitra \\ katarina.dancova@ukf.sk; jturzakova@ukf.sk; kbanasova@ukf.sk; mromanova@ukf.sk
}

\begin{abstract}
There is growing empirical evidence that personality characteristics play an important role in recovery after stroke. The aim of the submitted study is to critically evaluate findings concerning the relationship between personality characteristics and recovery outcome. Several multidisciplinary databases available to the authors of the review were searched for studies published since 2000. Twenty studies met the inclusion criteria. Most consistent findings suggest that high neuroticism is a predictor of poor patients' outcome represented by depression and low healthrelated quality of life. Methodological limits and suggestions for future research are discussed.
\end{abstract}

Keywords: stroke, personality, recovery, health-related quality of life, well-being, depression, anxiety

\section{INTRODUCTION}

Stroke is the third most leading cause of death in developed countries. The incidence of stroke has declined in many developed countries, mainly due to the control of high blood pressure, and reduced levels of smoking. However, the absolute number of strokes continues to increase because of the ageing population (Mackay \& Mensah, 2004). Stroke is a negative life event to which patients may respond with depression, depending on the interaction between personality factors and the severity of the negative physical, psychological, and social consequences of stroke (Aben et al., 2001). People after stroke experience long-term difficulties in their physical, cognitive, social and emotional functioning. Research has shown that stroke patients perceive lower health-related quality of life (HRQoL) than the general population (Kauhanen et al., 2000) which is still the case five years post stroke (De Wit et al., 2016). Research into the predictors of HRQoL has identified demographic and stroke-related factors, such as age, physical impairment, and functional independence, to be independent predictors of HRQoL (van Mierlo, Heugten, Post, Hoerkstra, \& Visser-Meily, 2017). Research shows HRQoL is determined mainly by disability and poststroke depression, female sex, coping strategies, and social support (Carod-Artal \& Egido, 2009. There is evidence that not only factors related to stroke and demographic data predict recovery but psychological variables are stronger predictors of recovery after stroke.

The role of personality factors as predictors of various illnesses is a part of psychology since the early psychosomatic theories. Psychological factors reflect the way people approach situations and adjust to chronic illness and therefore influence HRQoL (Visser-Meily, Rhebergen, Rinkel, van Zandvoort, \& Post, 2009; Taylor, Todman, \& Broomfield, 2011). Research on stroke has addressed the personality factors from various perspectives - mostly as pre-morbid characteristics of patients who experience stroke, personality factors as predictors of recovery after stroke, or changes in personality after stroke. A systematic review of big five personality factors and psychological well-being following stroke based on analysis of nine studies showed that people 
high on neuroticism are at increased risk of poor psychological well-being after stroke (Dwan \& Ownsworth, 2019). High neuroticism has been found to be a risk factor for poststroke depression (Aben et al., 2002), and high neuroticism and low agreeableness have been associated with poststroke agitation and irritability (Greenop, Almeida, Hankey, van Bockxmeer, \& Lautenschlager, 2009). In the field of psychology, other personality characteristics were also examined. Personality characteristic such as high depression, anxiety, passive coping, pessimism, helplessness, less selfefficacy, less acceptance, less extraversion, low proactive coping, less self-worth and low selfesteem were associated with worse quality of life in patients after stroke (Teoh, Sims, \& Milgrom, 2009; van Mierlo, Van Heugten, Post, De Kort, \& Visser-Meily, 2015; Tielemans, Schepers, VisserMeily, Post, \& Van Heugten, 2015; van Mierlo et al., 2017).

Depression is the most common personality change after stroke, predicted by neuroticism and history of mental disorder (Storor \& Byrne, 2006). Poststroke depression (PSD) is associated with physical disability, stroke severity, and cognitive impairment (Hackett, Yapa, Parag, \& Anderson, 2005). PSD affects HRQoL, functional recovery, cognitive function and healthcare use in stroke survivors (Carod-Artal \& Egido, 2009). It may lead to poorer prognosis and increased mortality (Poynter et al., 2009). Frequencies of PSD vary considerably across studies. Hackett et al. (2005) report the pooled estimate of 33\% (95\% confidence interval, $29 \%$ to $36 \%$ ) of all stroke survivors experiencing depression. In most stroke survivors the depression resolves spontaneously within several months of onset. PSD appears to be more common among women than men and among inpatient populations than in community-dwelling stroke survivors (Poynter et al., 2009). Increased age is related to increased likelihood of depression (Fruehwald, Loffler, Eher, Saletu, \& Baumhackl, 2001; Giaquinto et al., 1999).

While depression has received ample research attention, frequency, predictors and impact of anxiety after stroke remain less clear. Burton et al. (2013) carried out a systematic review and meta-analysis of 44 observational studies and found that the pooled estimate of anxiety disorders was $18 \%$ (95\% confidence interval $8-29 \%$ ) when assessed by clinical interview and 25\% (95\% confidence interval 21-28\%) when assessed by rating scale. The anxiety is linked to greater impairment in activities of daily living both acutely and up to 3 years post stroke (Schultz, Castillo, Kosier, \& Robinson, 1997). Co-morbidity of PSA and PSD is high, with as many as 85\% of people with generalized anxiety having co-morbid depression during the 3 years post stroke (Castillo et al., 1993, 1995).

Another frequently observed consequence of stroke is apathy, defined as reduced motivation or lack of initiative and motivation (Starkstein, Fedoroff, Price, Leiguarda, \& Robinson, 1993; Okada, Kobayashi, Yamagata, Takahashi, \& Yamaguchi, 1997; Yamagata, Yamaguchi, \& Kobayashi, 2004). The apathetic state after a stroke prevents patients from engaging in rehabilitation programs, resulting in delayed physical and social recovery (Hama et al., 2007).

\section{THE PRESENT STUDY}

The aim of the present study is to provide an overview of the current research, examining the role of personality variables in recovery of stroke survivors. There is growing evidence that personality plays an important role in recovery in patients after stroke (van Mierlo et al., 2017). The review aims to identify the variety of research objectives and most promising issues in current psychological research of the personality in stroke patients and its influence on recovery. In the present review study, we consider functional recovery, HRQoL, anxiety and depression as terms that reflect various areas of recovery. These variables are related to health outcomes. They are indicators of the health status in stroke patients, which were evaluated in reviewed studies. Therefore a better understanding of the role of personality in poststroke recovery may usefully 
inform rehabilitation and may help patients to cope with their disease condition effectively (Kim et al., 2013).

\section{METHODS}

To provide a review of current research on the topic, a literature search (from 2000 until 2019) was conducted. To locate relevant research literature the key words stroke, personality, HRQoL, recovery, depression, and anxiety were searched. Studies that were included in the review had to fit several criteria - reporting primary research, using quantitative methods, published in English between 2000-2019, published in one of several multidisciplinary databases available to the authors. Studies that did not meet the criteria were excluded (e.g. studies that use qualitative methods, studies published as conference proceeding, thesis, or book chapter, studies published in other than English language). Of the 54 articles retrieved, 20 articles were relevant to the aim of the study and met the inclusion criteria. Studies that met inclusion criteria were further analysed from the perspective of the objectives, study design, sample, methods of data collection and key findings.

\section{RESULTS}

The search identified 20 articles that were relevant to the aim of the study. Basic information about reviewed studies (author, year, country, design, sample, method, main findings) is presented in the table and more details are discussed in the following part.

Table 1 Studies included in the review (ranged ascending by year of publishing)

\begin{tabular}{|c|c|c|}
\hline $\begin{array}{c}\text { Author (year) } \\
\text { country }\end{array}$ & $\begin{array}{l}\text { Design, participants and method } \\
\text { (method of measurement, time of } \\
\text { measurement after stroke) }\end{array}$ & Key findings \\
\hline $\begin{array}{l}\text { Robinson- } \\
\text { Smith, } \\
\text { Johnston, \& } \\
\text { Allen (2000), } \\
\text { USA }\end{array}$ & $\begin{array}{l}\text { Longitudinal, descriptive correlational } \\
\text { design } \\
\mathrm{n}=63 \text { ( } 55 \% \text { male), mean age: } 71 \\
\text { Strategies Used by People to Promote } \\
\text { Health, Quality of Life Index - Stroke } \\
\text { Version, Center for Epidemiologic Studies } \\
\text { Depression Scale, Functional } \\
\text { Independence Measure (1 month and } 6 \\
\text { months after the stroke) }\end{array}$ & $\begin{array}{l}\text { Self-care self-efficacy increased after } \\
\text { stroke and was strongly correlated with } \\
\text { quality of life and depression at both } 1 \\
\text { and } 6 \text { months after stroke. Functional } \\
\text { independence and quality of life } \\
\text { increased over time, while depression } \\
\text { decreased. Functional independence was } \\
\text { modestly correlated with quality of life at } \\
6 \text { months after stroke, but not at } 1 \text { month } \\
\text { after stroke. }\end{array}$ \\
\hline $\begin{array}{l}\text { Gainotti, } \\
\text { Antonucci, } \\
\text { Marra, \& } \\
\text { Paolucci } \\
\text { (2001), Italy }\end{array}$ & $\begin{array}{l}\text { Retrospective analysis of available data } \\
\mathrm{n}=64 \text { ( } 56.25 \% \text { male), mean age: } 62 \\
\text { Hamilton depression rating scale, Barthel } \\
\text { index, Canadian neurological scale, } \\
\text { Rivermead mobility index (at the entry } \\
\text { into the clinic, after } 1 \text { month of } \\
\text { rehabilitation, at the end of the } \\
\text { rehabilitation) }\end{array}$ & $\begin{array}{l}\text { Non-treated depressed patients } \\
\text { presented the lowest rate of functional } \\
\text { recovery, whereas depressed but treated } \\
\text { patients with stroke had a recovery rate } \\
\text { similar to the non-depressed ones }\end{array}$ \\
\hline $\begin{array}{l}\text { Aben et al. } \\
(2002), \text { the } \\
\text { Netherlands }\end{array}$ & $\begin{array}{l}\text { Longitudinal design } \\
\mathrm{n}=54 \text { (53.2 \% male), mean age: } 68.6 \pm \\
11.7 \\
\text { Structured Clinical Interview for DSM-IV, } \\
\text { Hamilton Depression Rating Scale, NEO } \\
\text { Five-Factor Inventory, Mini Mental scale } \\
\text { examination, Barthel Index, Rankin score, } \\
\text { Frenchay Aphasia Screening Test } 1\end{array}$ & $\begin{array}{l}\text { Only neuroticism, as a vulnerability } \\
\text { factor for depression in the first year } \\
\text { after stroke, showed an independent } \\
\text { significant effect on the development of } \\
\text { PSD; men are more likely to have a great } \\
\text { depressive symptom as women; } 41 \\
\text { patients }(23.3 \%) \text { had major depressive }\end{array}$ \\
\hline
\end{tabular}




\begin{tabular}{|c|c|c|}
\hline & $\begin{array}{l}\text { month after stroke), Beck Depression } \\
\text { Inventory, Hospital Anxiety and } \\
\text { Depression scale, Symptom Checklist - } 90 \\
\text { (at } 3,6,9 \text {, and } 12 \text { months after stroke) }\end{array}$ & $\begin{array}{l}\text { disorder, and } 27(15.4 \%) \text { had minor } \\
\text { depressive disorder }\end{array}$ \\
\hline $\begin{array}{l}\text { Johnston et al. } \\
\text { (2004), United } \\
\text { Kingdom }\end{array}$ & $\begin{array}{l}\text { Longitudinal correlational } \begin{array}{c}\text { design } \\
\text { (assessment on } 6 \text { occasions between }\end{array} \\
\text { admission to hospital and } 3 \text { years after } \\
\text { stroke) } \\
n=101-40 \text { (because of patient's } \\
\text { mortality), } 52 \text { ( } 66.7 \% \text { male), mean age: } \\
65.6 \pm 9.1 \\
\text { Information and Statistics Division (ISD), } \\
\text { The Barthel Index of activities of daily } \\
\text { living (assessed on all } 6 \text { occasions), age, } \\
\text { gender and marital status; previous } \\
\text { stroke, side of stroke, abnormal CT scan, } \\
\text { fever, Ischaemic Heart Disease (IHD), } \\
\text { diabetes, atrial fibrillation, hyperglycemia } \\
\text { (on admission), Orgogozo Index, } \\
\text { Cognitive impairment Orientation section } \\
\text { of the Clifton Assessment Procedures for } \\
\text { the Elderly (CAPE; assessed at } 10-20 \text { days, } \\
1 \text { month, } 6 \text { months, and } 12 \text { months), } \\
\text { Mental Status Questionnaire (MSQ; } \\
\text { assessed at } 10-20 \text { days, } 1 \text { month, } 6 \\
\text { months, and } 12 \text { months), Hospital Anxiety } \\
\text { and Depression Scale (HADS; assessed at } \\
10-20 \text { days, } 1 \text { month, } 6 \text { months), Recovery } \\
\text { Locus of Control Scale (RLOC, assessed at } \\
10-20 \text { days, } 1 \text { month, } 6 \text { months) }\end{array}$ & $\begin{array}{l}\text { For functional recovery, multiple } \\
\text { regression analyses showed that fixed } \\
\text { clinical and demographic indexes } \\
\text { explained } 16 \% \text { to } 40 \% \text { of the variance in } \\
\text { recovery. Perceptions of control } 6 \\
\text { months after discharge added significant } \\
\text { to the predictive equations. Multiple } \\
\text { regression showed that no psychological } \\
\text { variables predicted survival. }\end{array}$ \\
\hline $\begin{array}{l}\text { Morrison et al. } \\
\text { (2005), United } \\
\text { Kingdom }\end{array}$ & $\begin{array}{l}\text { Longitudinal correlational design (data } \\
\text { were collected on three occasions: } 10-20 \\
\text { days poststroke and } 1 \text { and 6-months post } \\
\text { discharge) } \\
n=101-40 \text { (because of patient's } \\
\text { mortality), } 52 \text { ( } 66.7 \% \text { male), mean age: } \\
65.6 \pm 9.1 \\
\text { The Hospital Anxiety and Depression } \\
\text { Scale (HADS), age, gender, marital status, } \\
\text { living arrangements, side of lesion, } \\
\text { previous stroke, alcohol consumption, } \\
\text { and neurological impairment nine-item } \\
\text { index, Clifton Assessment Procedures for } \\
\text { the Elderly (CAPE), Mental Status } \\
\text { Questionnaire (MSQ), Barthel Index of } \\
\text { activities of daily living }\end{array}$ & $\begin{array}{l}\text { Anxiety remains stable over } 3 \text { years post } \\
\text { stroke and is best explained by prior, } \\
\text { early, anxiety, and female gender. } \\
\text { Depression reduces over time and was } \\
\text { explained by modifiable cognitions and } \\
\text { behaviours, which replicates previous } \\
\text { findings. In terms of predicting } 3 \text {-year } \\
\text { anxiety, only gender and earlier anxiety } \\
\text { were consistently significant. Depression } \\
3 \text { years after stroke was predicted by } \\
\text { earlier levels of handicap, anxiety, } \\
\text { exercise, and satisfaction, but not by any } \\
\text { clinical variables. Exercising at } 1 \text { month } \\
\text { was consistently predictive of lower } \\
\text { depression at } 3 \text { years (controlling for } \\
\text { each previous level of depression). }\end{array}$ \\
\hline $\begin{array}{c}\text { Storor \& Byrne } \\
\text { (2006), } \\
\text { Australia }\end{array}$ & $\begin{array}{l}\text { Cross-sectional correlation design } \\
\text { (assessment during acute phase post } \\
\text { stroke) } \\
\mathrm{n}=61,25(41 \% \text { male), mean age: } 71.9 \pm \\
13.6 \text { Interview (data of age, gender, } \\
\text { marital status, type of accommodation } \\
\text { and education), CT scans, MMSE - }\end{array}$ & $\begin{array}{l}\text { Self-rated depression and clinician-rated } \\
\text { depression were strongly associated } \\
\text { with informant-rated neuroticism. } \\
\text { Individual premorbid differences, rather } \\
\text { than stroke characteristics, are more } \\
\text { important predictors of depressive } \\
\text { symptoms in stroke patients. Informant- }\end{array}$ \\
\hline
\end{tabular}




\begin{tabular}{|c|c|c|}
\hline & $\begin{array}{l}\text { cognitive status, MBI - basic activities of } \\
\text { daily living, Modified Barthel Index, } \\
\text { Instrumental Activities of Daily Living } \\
\text { Scale (IADL), Personality Inventory- } \\
\text { Revised (NEO), Composite International } \\
\text { Diagnostic Interview, CIDI-Auto version, } \\
\text { Hamilton Depression Rating Scale (HAM- } \\
\text { D), self-report Center for Epidemiologic } \\
\text { Studies Depression Scale (CES-D) }\end{array}$ & $\begin{array}{l}\text { rated pre-morbid neuroticism and a past } \\
\text { history of mental disorder were found to } \\
\text { be important predictors of depression } \\
\text { following stroke. }\end{array}$ \\
\hline $\begin{array}{c}\text { Barker-Collo } \\
\text { (2007) } \\
\text { New Zealand }\end{array}$ & 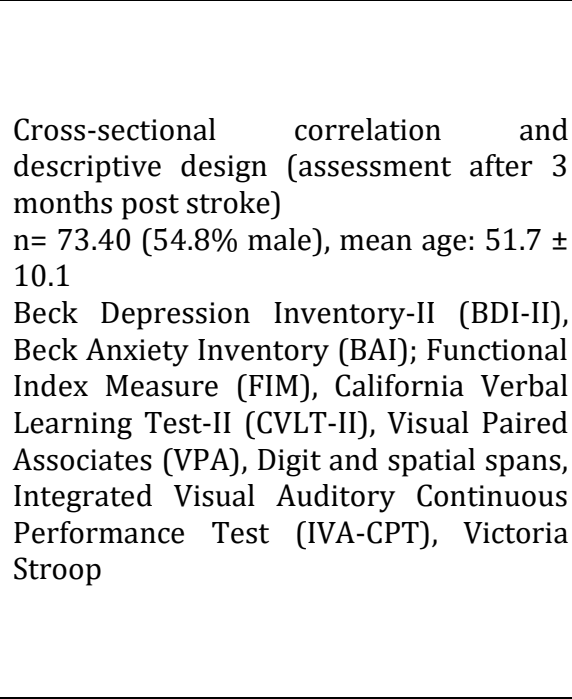 & $\begin{array}{l}\text { Prevalence of moderate to severe } \\
\text { depression and anxiety in the sample } \\
\text { were high (22.8 and } 21.1 \% \text {, } \\
\text { respectively), with co-morbidity in } \\
12.3 \% \text { of cases. Most of }(74.6 \%) \text { variance } \\
\text { in depression was explained with } \\
\text { significant relationships between } \\
\text { increased depression and younger age, } \\
\text { reduced cognitive speed, poorer verbal } \\
\text { memory, left hemisphere lesion, and } \\
\text { increased impact of interference (Stroop } \\
\text { ratio). Left hemisphere of lesion also } \\
\text { contributed to prediction of anxiety, } \\
\text { explaining } 50.7 \% \text { of the variance. While } \\
\text { age and hemisphere of lesion } \\
\text { contributed, cognitive performance } \\
\text { explained the greatest proportion of } \\
\text { variance in both depression and anxiety } \\
\text { (51.3 and 38.5\%, respectively). }\end{array}$ \\
\hline$\frac{\text { Hama et al. }}{(2007) \text {, Japan }}$ & $\begin{array}{l}\text { Cross-sectional correlation } \\
\text { comparational design (assessment less } \\
\text { than } 2 \text { months after stroke) } \\
\mathrm{n}=237(65,8 \% \text { male), mean age: } 65.1 \pm \\
11.3 \\
\text { the Zung Self-Rating Depression Scale } \\
\text { (SDS), Apathy Scale (AS), the } \\
\text { Neuropsychiatric Inventory (NPI), } \\
\text { Functional Independence Measurement } \\
\text { (FIM), Mini Mental State Examination } \\
\text { (MMSEs) }\end{array}$ & $\begin{array}{l}\text { The findings from this study do not } \\
\text { suggest that psychological symptoms } \\
\text { cause functional deficits; rather they } \\
\text { indicate that psychological symptoms, } \\
\text { especially apathy, are frequently } \\
\text { associated with functional abilities and } \\
\text { likely interact with the recovery process. } \\
\text { The cognitive variable MMSE score and } \\
\text { AS score, correlated negatively with } \\
\text { improvement in FIM. }\end{array}$ \\
\hline $\begin{array}{c}\text { Greenop, } \\
\text { Almeida, } \\
\text { Hankey, van } \\
\text { Bockxmeer, \& } \\
\text { Lautenschlager } \\
\text { (2009), } \\
\text { Australia }\end{array}$ & $\begin{array}{l}\text { Prospective, observational, three-month } \\
\text { follow-up study } \\
\mathrm{n}=51(66.7 \% \text { male), mean age } 65.6 \pm 10.9 \\
\text { NEO Personality Inventory-Revised } \\
\text { (informant, within four weeks after the } \\
\text { stroke), Cambridge Examination for } \\
\text { Mental Disorders of the Elderly- Revised- } \\
\text { cognitive section, Hospital Anxiety and } \\
\text { Depression Scale (3 months after), } \\
\text { Neuropsychiatric Inventory- carer } \\
\text { distress version and instrumental } \\
\text { activities of daily living scale (informant, } 3 \\
\text { months after). }\end{array}$ & $\begin{array}{l}\text { Premorbid personality traits of high } \\
\text { neuroticism and low agreeableness are } \\
\text { associated with the presence of post- } \\
\text { stroke agitation, irritability, and carer } \\
\text { distress three months post-stroke. }\end{array}$ \\
\hline
\end{tabular}




\begin{tabular}{|c|c|c|}
\hline $\begin{array}{l}\text { Teoh et al. } \\
\text { (2009), } \\
\text { Australia }\end{array}$ & $\begin{array}{l}\text { Longitudinal design } \mathrm{n}=135 \text { (68.1 } \% \\
\text { male), mean age: } 67.5 \pm 14.3 \\
\text { Assessment of Quality of Life, the Stroke } \\
\text { Impact Scale, the Satisfaction with Life } \\
\text { Scale, Short Form- } 12 \text { Health Survey, } \\
\text { Center for Epidemiologic Studies } \\
\text { Depression scale, The Patient Health } \\
\text { Questionnaire, The Medical Outcome } \\
\text { Study Social Support Survey, Life } \\
\text { Orientation Test-Revised, Rosenberg Self- } \\
\text { Esteem Scale, Recovery Locus of Control } \\
\text { scale, Modified Rankin Scale (at baseline, } \\
10 \text { weeks and } 6 \text { months) }\end{array}$ & $\begin{array}{l}26 \% \text { of patients had depression } \\
\text { symptoms. Depressed participants had } \\
\text { poor HRQoL, social support, optimism, } \\
\text { self-esteem, perceived control, and } \\
\text { physical functioning. There were } \\
\text { improvements in participants' physical } \\
\text { health, social participation, depressive } \\
\text { status, and optimism over the course of } \\
\text { the study. }\end{array}$ \\
\hline $\begin{array}{l}\text { Donnellan et } \\
\text { al. (2010), } \\
\text { Ireland }\end{array}$ & $\begin{array}{l}\text { Longitudinal design } \\
\text { n= } 107 \text { ( } 51.0 \% \text { male), age: range 20-98; } \\
\text { over } 65 \text { years } 35 \% \text {, under } 65 \text { years } 65 \% \\
\text { Frenchay Aphasia Screening Test, } \\
\text { Abbreviated Mental Test, The Nottingham } \\
\text { Extended Activities of Daily Living Scale, } \\
\text { Orpington Prognostic Score, Stroke- } \\
\text { Specific Quality of Life scale, Hospital } \\
\text { Anxiety and Depression scale (1 month } \\
\text { and } 1 \text { year after stroke) }\end{array}$ & $\begin{array}{l}\text { The prevalence of depression and } \\
\text { anxiety symptoms was } 35 \% \text { at one } \\
\text { month and } 36 \% \text { and } 34 \% \text {, respectively, } \\
\text { at one year; anxiety symptoms did } \\
\text { decrease significantly over time but } \\
\text { depression symptoms did not; here was } \\
\text { no significant improvement in HRQoL } \\
\text { over time considering there was } \\
\text { improvement in functional ability (FA); } \\
\text { depression predicted HRQoL and FA, } \\
\text { anxiety predicted HRQoL but not FA at } \\
\text { both time points. }\end{array}$ \\
\hline $\begin{array}{l}\text { Hwang et al. } \\
\text { (2011), Korea }\end{array}$ & $\begin{array}{l}\mathrm{n}=45 \text { (62.22\% male), mean age: } 47.5 \pm \\
11.2 \\
\text { Beck Depression Inventory (patient), } \\
\text { Hamilton Rating Scale for Depression, } \\
\text { NEO-PI (informant) }\end{array}$ & $\begin{array}{l}\text { Neuroticism is the only factor which is } \\
\text { significantly correlated with depression } \\
\text { scales in stroke patients. }\end{array}$ \\
\hline $\begin{array}{c}\text { Afanasiev, } \\
\text { Aharon- } \\
\text { Peretz, \& } \\
\text { Granot (2013), } \\
\text { Israel }\end{array}$ & $\begin{array}{l}\text { Prospective, three-month follow-up study } \\
\mathrm{n}=70(72.9 \% \text { male), mean age: } 63.5 \pm 9.7 \\
\text { Cloninger's Tridimensional Personality } \\
\text { Questionnaire, National Institutes of } \\
\text { Health Stroke Scale (after the stroke), } \\
\text { Beck Depression Inventory, Stroke } \\
\text { Specific Quality of Life questionnaire (3 } \\
\text { months after) }\end{array}$ & $\begin{array}{l}\text { Higher harm avoidance scores } \\
\text { independently predicted PSDS and } \\
\text { reduction in QOL. After controlling for } \\
\text { the relative contribution of stroke type } \\
\text { and health-related variables, HA and } \\
\text { neurologic deficit were significant risk } \\
\text { factors for poststroke negative } \\
\text { outcomes. }\end{array}$ \\
\hline $\begin{array}{l}\text { Kim et al. } \\
\text { (2013), South } \\
\text { Korea }\end{array}$ & $\begin{array}{l}\text { Longitudinal design } \\
\mathrm{n}=151 \text { ( } 56.3 \% \text { male), mean age: } 64.1 \pm \\
9.4 \\
\text { National Institutes of Health Stroke Scale, } \\
\text { Barthel Index ( } 2 \text { weeks after stroke), Big } \\
\text { Five Inventory ( } 3 \text { months), The World } \\
\text { Health Organization Quality of Life } \\
\text { Assessment abbreviated Version ( } 2 \text { weeks } \\
\text { and } 3 \text { months) }\end{array}$ & $\begin{array}{l}\text { Neuroticism predicted QOL levels in all } 4 \\
\text { domains, and extraversion, } \\
\text { agreeableness and conscientiousness } \\
\text { influenced some, but not all, QOL } \\
\text { domains. There were few influences on } \\
\text { change in QOL but openness trait had no } \\
\text { influence on overall QOL levels but } \\
\text { showed significant group-by time } \\
\text { interactions on psychological and } \\
\text { environment QOL domains. }\end{array}$ \\
\hline $\begin{array}{l}\text { Morris, Van } \\
\text { Wijck, Joice, \& } \\
\text { Donaghy } \\
\text { (2013), United } \\
\text { Kingdom }\end{array}$ & $\begin{array}{l}\text { Cross-sectional, 6-months follow-up } \\
\text { study } \\
\text { n= } 85(57.65 \% \text { male), mean age: } 67.5 \pm \\
11.4 \\
\text { Nottingham Health Profile, Hospital } \\
\text { Anxiety and Depression Scale, Action }\end{array}$ & $\begin{array}{l}\text { Anxiety was the strongest predictor of } \\
\text { overall HRQoL. }\end{array}$ \\
\hline
\end{tabular}




\begin{tabular}{|c|c|c|}
\hline & $\begin{array}{l}\text { Research Arm Test; Rivermead Motor } \\
\text { Assessment, Modified Barthel Index }\end{array}$ & \\
\hline $\begin{array}{l}\text { Mierlo et al. } \\
\text { (2015), the } \\
\text { Netherlands }\end{array}$ & $\begin{array}{l}\text { Cross-sectional study } \\
\text { n=344 (64.0\% male), mean age: } 66.9 \pm \\
12.3 \\
\text { Hospital Anxiety and Depression scale, } \\
\text { Eysenck Personality Questionnaire } \\
\text { Revised Short Scale (N-E), Life } \\
\text { Orientation Test-Revised, General Self- } \\
\text { Efficacy Scale, Illness Cognition } \\
\text { Questionnaire, Proactive Coping } \\
\text { Competence List, Utrecht Coping List, } \\
\text { Barthel Index, Heteroanamnesis List } \\
\text { Cognition, National Institutes of Health } \\
\text { Stroke Scale, Montreal Cognitive } \\
\text { Assessment (patients assessed at 2 } \\
\text { months poststroke) }\end{array}$ & $\begin{array}{l}21.5 \% \text { of the participants experienced } \\
\text { depressive symptoms. The presence of } \\
\text { PSDS was associated with higher levels } \\
\text { of neuroticism, pessimism, helplessness, } \\
\text { and passive coping, and lower levels of } \\
\text { extraversion, optimism, self-efficacy, } \\
\text { acceptance, perceived benefits, and } \\
\text { proactive coping. }\end{array}$ \\
\hline $\begin{array}{l}\text { Tielemans et } \\
\text { al. (2015), the } \\
\text { Netherlands }\end{array}$ & $\begin{array}{l}\text { Cross-sectional study } \\
\mathrm{n}=112(52.7 \% \text { male), mean age: } 57.1 \pm 8.9 \\
\text { Utrecht Proactive Coping Competence } \\
\text { scale, General Self-Efficacy Scale, Utrecht } \\
\text { Scale for Evaluation of Rehabilitation- } \\
\text { Participation, Hospital Anxiety and } \\
\text { Depression Scale, life satisfaction with the } \\
\text { use of } 2 \text { questions, Short Stroke-Specific } \\
\text { Quality of Life scale (patients assessed at } \\
5 \text { days poststroke) }\end{array}$ & $\begin{array}{l}\text { Proactive coping was associated with all } \\
\text { of the psychosocial outcomes, except for } \\
\text { participation restrictions. Self-efficacy } \\
\text { was associated with emotional } \\
\text { functioning, life satisfaction, and HRQoL. } \\
\text { Self-efficacy was indirectly associated } \\
\text { with emotional functioning through } \\
\text { proactive coping. Unexpectedly, } \\
\text { proactive coping was indirectly } \\
\text { associated with HRQoL through self- } \\
\text { efficacy. }\end{array}$ \\
\hline $\begin{array}{c}\text { Lapadatu \& } \\
\text { Morris (2017), } \\
\text { south Wales } \\
\text { and south west } \\
\text { England }\end{array}$ & $\begin{array}{l}\text { Cross-sectional study } \\
\mathrm{n}=65 \text { stroke survivors ( } 44.6 \% \text { male), } \\
\text { mean age: } 61.5 \pm 11.4 \\
\text { Head Injury Semantic Differential Scale- } \\
\text { III, Hospital Anxiety and Depression scale, } \\
\text { Rosenberg Self- Esteem Scale, Stroke- } \\
\text { Specific Quality of Life Questionnaire, } \\
\text { Barthel Index (time of assessment not } \\
\text { defined- participants must have } \\
\text { experienced one stroke six months to } 15 \\
\text { years previously) }\end{array}$ & $\begin{array}{l}\text { Those with a greater discrepancy in } \\
\text { evaluation after stroke had lower self- } \\
\text { esteem and quality of life and were more } \\
\text { depressed and anxious. Survivors rated } \\
\text { themselves significantly less positively } \\
\text { after stroke. Depression predicts a } \\
\text { negative view of current self, but they } \\
\text { also predict a negative view of the past } \\
\text { and future self. }\end{array}$ \\
\hline $\begin{array}{l}\text { Solgajová, } \\
\text { Sollár, } \\
\text { Vörösová, \& } \\
\text { Zrubcová } \\
\text { (2017), } \\
\text { Slovakia }\end{array}$ & $\begin{array}{l}\text { Prospective cross-sectional descriptive } \\
\text { design } \\
\mathrm{n}=74 \text { (59.5\% male), mean age } 66.64 \pm \\
11.97 \\
\text { Hospital Anxiety and Depression Scale, } \\
\text { Mini IPIP (International personality item } \\
\text { pool measuring Big five dimensions) }\end{array}$ & $\begin{array}{l}\text { Neuroticism and low Agreeableness } \\
\text { explain } 50 \% \text { of the variability of anxiety. } \\
\text { Another statistically significant } \\
\text { predictor was age; higher-level anxiety } \\
\text { relates to lower age. Other personality } \\
\text { traits (Extraversion, Openness to } \\
\text { experience, and Conscientiousness), } \\
\text { gender, and type of stroke do not appear } \\
\text { as significant predictors of post-stroke } \\
\text { anxiety. }\end{array}$ \\
\hline $\begin{array}{l}\text { Mierlo et al. } \\
\text { (2017), the } \\
\text { Netherlands }\end{array}$ & $\begin{array}{l}\text { Longitudinal design } \\
\mathrm{n}=351 \text { ( } 64.4 \% \text { male), mean age: } 66.8 \pm \\
12.5 \\
\text { Short Stroke Specific Quality of Life Scale } \\
(2,6 \text { and } 12 \text { months after stroke), Eysenck }\end{array}$ & $\begin{array}{l}\text { Four trajectories were identified for both } \\
\text { physical and psychosocial HRQoL: stable } \\
\text { high, stable low, recovery, and decline. } \\
\text { The groups with low HRQoL were more } \\
\text { likely to have higher scores for }\end{array}$ \\
\hline
\end{tabular}




\begin{tabular}{|l|l|l|}
\hline & $\begin{array}{l}\text { Personality Questionnaire Revised Short } \\
\text { Scale (N-E), Life Orientation Test-Revised, }\end{array}$ & $\begin{array}{l}\text { neuroticism. Decline and high } \\
\text { trajectories yielded the following } \\
\text { General Self-Efficacy Scale, Illness } \\
\text { predictors of physical HRQoL: less }\end{array}$ \\
Cognition Questionnaire, Utrecht & acceptance and more neuroticism, \\
Proactive Coping Competence List, & pessimism, helplessness, and passive \\
Utrecht Coping List 2 months post & coping. Predictors of psychosocial \\
stroke), Heteroanamnesis List Cognition, & HRQoL were: less self-efficacy, and \\
National Institutes of Health Stroke Scale & proactive coping, and more helplessness \\
(4 days after stroke), Cumulative Illness & and passive coping. \\
Rating scale, Montreal Cognitive & \\
Assessment, Barthel Index (4 days and 2 \\
months after stroke)
\end{tabular}

DISCUSSION

The aim of the present study was to review current literature on personality characteristics and their relation to the outcome in stroke survivors. Most studies were carried out in western countries (USA, Italy, United Kingdom, Netherlands, Australia, New Zealand, Slovakia), only three report data from non-western countries - Korea (Hwang et al., 2011), South Korea (Kim et al., 2013) and Japan (Hama et al., 2007).

\section{Objectives of the reviewed studies}

The main objective of the reviewed studies was to critically evaluate findings concerning the effect of personality on patients' recovery. Our study provides a wide range of research in this field and reviewed studies also aimed to explore some specific aspects of the effect of personality on patients' recovery. Robinson-Smith et al. (2000) explored the relationships of self-care selfefficacy, quality of life, and depression after stroke. Gainotti et al. (2001) focused on relation between depression after stroke, antidepressant therapy, and functional recovery. Aben et al. (2002) explored which personality characteristics are potential vulnerability factors for poststroke depression (PSD). Johnston, Pollard, Morrison, \& MacWalter (2004) examined the additional predictive value of psychological predictors of functional outcomes of stroke. Morrison, Pollard, Johnston, \& MacWalter (2005) examined demographic, clinical and psychological predictors. Storor \& Byrne (2006) in cross-sectional design investigated the relationship between premorbid personality and depression following acute stroke. Also, the prevalence of depression and anxiety as well as the relationships of age, gender, hemisphere of lesion, functional independence and cognitive functioning to depression and anxiety at 3 months post stroke patients were examined (Barker-Collo, 2007). Hama et al. (2007) in addition to depression assessed poststroke apathy and its effect on functional outcome. Greenop et al. (2009) examined associations of premorbid personality traits with post-stroke behavioral and psychological symptoms. Teoh et al. (2009) focused on psychosocial predictors of quality of life. Donnellan, Hickey, Hevey, \& O'Neill (2010) examined the effect of depression and anxiety on HRQoL and functional recovery at 1 month and one year after stroke. Hwang et al. (2011) explored correlations between pre-morbid personality and depression. Afanasiev et al. (2013) focused on personality type as a predictor for depressive symptoms and reduction in quality of life. Kim (2013) explored the impact of personality traits on quality of life after stroke. Morris (2013) examined the role of anxiety and upper limb dysfunction in predicting HRQoL 6 months after stroke. Van Mierlo et al. (2015) explored the course of HRQoL in patients after 6 months after stroke in cross-sectional study. Tielemans et al. (2015) examined the associations of proactive coping, self-efficacy, emotional responses with psychosocial outcomes such as quality of life in patients after stroke. Lapadatu and Morris (2017) focused on changes in perceived identity after stroke and explained their relationship with mood and quality of life. Solgajová et al. (2017) examined Big Five personality factors that predict post-stroke anxiety. Van 
Mierlo et al. (2017) focused on psychological, demographical and stroke-related factors and their association with HRQoL at 1 month and 6 months after stroke.

\section{Designs of the reviewed studies}

Most of reviewed studies (Johnston et al., 2004; Morrison et al., 2005; Robinson-Smith, Johnston, \& Allen, 2000; I. Aben et al., 2002; Greenop et al., 2009; Teoh et al., 2009; Afanasiev, Aharon-Peretz, \& Granot, 2013; Kim et al., 2013) had longitudinal design, which is suitable in this specific field. Longitudinal design allows examining the changes in quality of life during recovery after stroke and may propose the most relevant solutions in rehabilitation with the goal to improved quality of life of patients. Another research design was cross-sectional (Gainotti et al., 2001; Storor \& Byrne, 2006; Barker-Collo, 2007; Hama et al., 2007; Hwang et al., 2011; Morris et al., 2013; van Mierlo et al., 2015; Tielemans et al., 2015; Lapadatu \& Morris, 2017, Solgajová et al., 2017).

The measurement tools used in studies can be divided into following categories: clinical tools (measures of neurological, physical and cognitive impairment), psychological tools (psychological inventories and tests) and methods to detect demographic data (interview, questionnaires). In most of the conducted studies, the source of data was the patient, only two studies (Greenop et al., 2009; Hwang et al., 2011) used the data collected from informants (person taking care of a stroke survivor, e.g. spouse, son, or daughter).

In almost all studies the mean age of the participants was over 60 years. There were slightly more men than women in the sample. Due to the restricted inclusion criteria, the patients with serious impairment were in most studies excluded from the data collection.

\section{Outcome variables and their predictors}

The recovery or survival of patients is defined mostly as well-being or quality of life (RobinsonSmith, Johnston, \& Allen 2000; Afanasiev, Aharon-Peretz, \& Granot, 2013; Morris et al., 2013; Teoh et al., 2009; Donnellan et al., 2010; Tielemans et al., 2015; Lapadatu \& Moris, 2017; van Mierlo et al., 2017) or physical independence (Hama et al. ,2007; Robinson-Smith, Johnston, \& Allen, 2000; Gainotti et al., 2001).

Overall, the most consistent finding was that higher neuroticism was related to poorer well-being of patients. This was supported by eight studies (Storor \& Byrne, 2006; Morris et al., 2013; van Mierlo et al., 2015; Tielemans et al., 2015; Lapadatu \& R. Morris, 2017, van Mierlo et al., 2017; Hwang et al., 2011; Kim et al., 2013). Higher neuroticism is also related to the presence of carer distress (Greenop et al., 2009). Another personality characteristics such as high depression, anxiety, passive coping, pessimism, helplessness, less self-efficacy, less acceptance, less extraversion, low proactive coping, and low self-esteem were associated with worse quality of life in patients after stroke (Gainotti et al., 2001; Teoh et al. 2009; van Mierlo et al., 2015; Tielemans et al., 2015; van Mierlo et al., 2017).

Symptoms of depression in stroke patients were associated with higher levels of neuroticism, pessimism, helplessness, and passive coping, and lower levels of extraversion, optimism, selfefficacy, acceptance, perceived benefits, proactive coping (van Mierlo et al., 2015), earlier levels of handicap, anxiety, exercise, and satisfaction (Morrison et al., 2005) and past history of mental disorder (Storor \& Byrne, 2006). Anxiety is also very strong predictor of HRQoL (Morris et al., 2013) and remains stable over 3 years post stroke (Morrison et al., 2005). The prevalence of depressive and anxiety symptoms of post stroke patients were also examined. Prevalence of moderate to severe depression was 22.8 - 36\% (Barker-Collo, 2007; Donnellan et al., 2010, van Mierlo et al., 2015) and anxiety was 21.1 - 35\% (Barker-Collo, 2007; Donnellan et al., 2010), with co-morbidity in 12,3\% of cases (Barker-Collo, 2007.) Men are more likely to have great depressive 
symptoms than women (Aben, et al., 2002). However, apathy might be more frequently associated with functional abilities and likely interact with the recovery process when compared with depression after stroke (Hama, et al., 2007). According to Storor \& Byrne (2006) stroke side was not significantly related to risk of depressive symptoms following stroke. However Åström (1996) concludes that PSA correlates significantly with right hemisphere lesions, while co-morbid PSA and PSD are linked to left hemisphere lesions. Left hemisphere lesions may also be linked to increased level of depression and anxiety (Barker-Collo, 2007).

Early recovery of functional ability and initial self-evaluated HRQoL are viewed as very important in determining recovery one year later. Further clinical studies determining long-term recovery after stroke should be controlling for initial recovery, such as early improvements in functional ability during the acute period in tandem with premorbid conditions, in order to determine more precisely the independent variables that are actually predicting outcome (Donnellan et al. 2010). In addition, the results suggest that rehabilitation might focus on enhancing self-esteem which has a key role in determining the outcome (Lapadatu \& Moris, 2017).

The strengths of our study can be perceived in two basic domains: (a) evaluation of different type of research designs and, (b) evaluation of the outcomes in research studies related to poststroke recovery. Our intention was to take into account various personality characteristics, e.g. five factor model of personality, self-efficacy, self-worth, locus of control, helplessness, coping strategies, identity, apathy and consider their potential impact on recovery in stroke patients. There are some threats to validity of the results included in the reviewed studies. Firstly, the results may be influenced by the use of various questionnaires measuring the outcome variables, various cut-off scores used to determine the diagnosis, or various sources of information (self-report vs. informant rating). In some studies, the data were collected from the informants, usually the caregivers (e.g. spouse, son or daughter). Their ratings might be affected by their own personality or current distress caused by taking care of the stroke patient. Another issue is related to a "healthy recruitment bias" which means that patients with more serious health status or substantial cognitive impairment did not participate in the study. Patients with another psychiatric illness (major depression, bipolar disorder, schizophrenia), or with comprehension deficits (aphasia, cognitive impairment) were excluded from the studies (Johnston et al., 2004; Storor \& Byrne, 2006; Barker-Collo, 2007; Hama et al., 2007; Morrison et al., 2005). As a result, the samples may not represent general stroke population.

\section{CONCLUSION}

The aim of the present review was to provide an overview of current research on the relationship between personality characteristics and poststroke recovery. The findings of the study emphasize the need to consider personality as a potential determinant of recovery outcomes such as wellbeing, quality of life, recovery, depression and anxiety after stroke. As Dwan \& Ownsworth (2019) suggest assessing personality characteristics after stroke may help identify those patients who are at risk of poor psychological well-being. Asking about patients' personality styles should assist in screening for those who are at risk of developing depression (Storor \& Byrne, 2006). Better understanding of the role of personality in poststroke recovery may usefully inform rehabilitation and may help patients cope with their disease conditions effectively (Kim et al., 2013). The results suggest that rehabilitation might focus on enhancing those psychological factors that increase patients' health status, functional recovery and quality of life after stroke. Cognitions and mood poststroke are linked and both should be addressed as parts of the rehabilitative process (BarkerCollo, 2007). The cognitions are modifiable; they offer opportunities for intervention to improve patient outcome (Johnston et al., 2004). It is recommended that rehabilitation programs should be more multidimensional. The overall goals are to promote the adoption of better adaptation and 
coping strategies by the individual such that they achieve their highest possible HRQoL (Teoh et al., 2009). Further research should investigate the effect of personality in poststroke patients on recovery longitudinally, and promote their coping strategies.

\section{REFERENCES}

Aben, I., Verhey, F., Honig, A., Lodder, J., Lousberg, R., \& Maes, M. (2001). Research into the specificity of depression after stroke: a review on an unresolved issue. Progress NeuroPsychopharmacology and Biological Psychiatry, 25(4), 671-689. DOI: 10.1016/S02785846(01)00158-0

Aben, I., Denollet, J., Lousberg, R., Verhey, F., Wojciechowski, F., \& Honig, A. (2002). Personality and vulnerability to depression in stroke patients: a 1-year prospective follow-up study. Stroke, 33(10), 2391-2395. DOI: 10.1161/01.STR.0000029826.41672.2E

Afanasiev, S., Aharon-Peretz, J., \& Granot, M. (2013). Personality type as a predictor for depressive symptoms and reduction in quality of life among stroke survivals. The American Journal of Geriatric Psychiatry, 21(9), 832-839. DOI: 10.1016/j.jagp.2013.04.012

Åström, M. (1996). Generalized anxiety disorder in stroke patients: a 3-year longitudinal study. Stroke, 27(2), 270-275. DOI: 10.1161/01.STR.27.2.270

Barker-Collo, S. L. (2007). Depression and anxiety 3 months post stroke: prevalence and correlates. Archives of Clinical Neuropsychology, 22(4), 519-531. DOI: 10.1016/j.acn.2007.03.002

Burton, C. A. C., Murray, J., Holmes, J., Astin, F., Greenwood, D., \& Knapp, P. (2013). Frequency of anxiety after stroke: a systematic review and meta-analysis of observational studies. International Journal of Stroke, 8(7), 545-559. DOI: 10.1111/j.1747-4949.2012. 00906.x

Carod- Artal, F. J., \& Egido, J. A. (2009). Quality of life after stroke: the importance of a good recovery. Cerebrovascular diseases, 27 (Suppl. 1), 204-214. DOI: 10.1159/000200461

Castillo, C. S., Schultz, S. K., \& Robinson, R. (1995). Clinical correlates of early-onset and late-onset poststroke generalised anxiety. American Journal of Psychiatry, 152(8), 1174-1181. DOI: 10.1176/ajp.152.8.1174

Castillo, C. S., Starkstein, S. E., Fedoroff, J. P., \& Price, T. R. (1993). Generalized anxiety disorder after stroke. Journal of Nervous \& Mental Disease, 181(2), 100-106. DOI: 10.1097/00005053199302000-00005

De Wit, L., Theuns, P., Dejaeger, E., Devos, S., Gantenbein, A. R., Kerckhofs, E., ... \& Putman, K. (2017). Long-term impact of stroke on patients' health-related quality of life. Disability and rehabilitation, 39(14), 1435-1440. DOI: 10.1080/09638288.2016.1200676

Donnellan, C., Hickey, A., Hevey, D., \& O'neill, D. (2010). Effect of mood symptoms on recovery one year after stroke. International journal of geriatric psychiatry, 25(12), 1288-1295. DOI: 10.1002 /gps.2482

Dwan, T., \& Ownsworth, T. (2019). The Big Five personality factors and psychological well-being following stroke: a systematic review. Disability and rehabilitation, 41(10), 1119-1130. DOI: 10.1080/09638288.2017.1419382

Frühwald, S., Löffler, H., Eher, R., Saletu, B., \& Baumhackl, U. (2001). Relationship between depression, anxiety and quality of life: a study of stroke patients compared to chronic low back pain and myocardial ischemia patients. Psychopathology, 34(1), 50-56. DOI: 10.1159/000049280 
Gainotti, G., Antonucci, G., Marra, C., \& Paolucci, S. (2001). Relation between depression after stroke, antidepressant therapy, and functional recovery. Journal of Neurology, Neurosurgery \& Psychiatry, 71(2), 258-261. DOI: 10.1136/jnnp.71.2.258

Giaquinto, S., Buzzelli, S., Francesco, L. D., Lottarini, A., Montenero, P., \& Tonin, P. (1999). On the prognosis of outcome after stroke. Acta Neurologica Scandinavica, 100(3), 202-208. DOI: 10.1111/j.1600-0404.1999.tb00740.x

Greenop, K. R., Almeida, O. P., Hankey, G. J., van Bockxmeer, F., \& Lautenschlager, N. T. (2009). Premorbid personality traits are associated with post-stroke behavioral and psychological symptoms: a three-month follow-up study in Perth, Western Australia. International psychogeriatrics, 21(6), 1063-1071. DOI: 10.1017/S1041610209990457

Hackett, M. L., Yapa, C., Parag, V., \& Anderson, C. S. (2005). Frequency of depression after stroke: a systematic review of observational studies. Stroke, 36(6), 1330-1340. DOI: 10.1161/01.STR.0000165928.19135.35

Hama, S., Yamashita, H., Shigenobu, M., Watanabe, A., Hiramoto, K., Kurisu, K., ... \& Kitaoka, T. (2007). Depression or apathy and functional recovery after stroke. International Journal of Geriatric Psychiatry: A journal of the psychiatry of late life and allied sciences, 22(10), 1046-1051. DOI: $10.1002 /$ gps.1866

Hwang, S. I., Choi, K. I., Park, O. T., Park, S. W., Choi, E. S., \& Yi, S. H. (2011). Correlations between pre-morbid personality and depression scales in stroke patients. Annals of rehabilitation medicine, 35(3), 328. DOI: 10.5535/arm.2011.35.3.328

Johnston, M., Pollard, B., Morrison, V., \& MacWalter, R. (2004). Functional limitations and survival following stroke: psychological and clinical predictors of 3-year outcome. International journal of behavioural medicine, 11(4), 187. DOI: 10.1207/s15327558ijbm1104_1

Kauhanen, M. L., Korpelainen, J. T., Hiltunen, P., Nieminen, P., Sotaniemi, K. A., \& Myllylä, V. V. (2000). Domains and determinants of quality of life after stroke caused by brain infarction. Archives of physical medicine and rehabilitation, 81(12), 1541-1546. DOI: 10.1053/apmr.2000.9391

Kim, S. Y., Kim, J. M., Stewart, R., Kang, H. J., Kim, S. W., Shin, I. S., ... \& Yoon, J. S. (2013). Influences of personality traits on quality of life after stroke. European neurology, 69(3), 185-192. DOI: $10.1159 / 000345699$

Lapadatu, I., \& Morris, R. (2017). The relationship between stroke survivors' perceived identity and mood, self-esteem and quality of life. Neuropsychological rehabilitation, 29(2), 199-213. DOI: 10.1080/09602011.2016.1272468

Mackay, J. \& Mensah, G. (2004). The Atlas of Heart Disease and Stroke. WHO. ISBN 9789241562768. $112 \mathrm{p}$.

Morris, J. H., Van Wijck, F., Joice, S., \& Donaghy, M. (2013). Predicting health related quality of life 6 months after stroke: the role of anxiety and upper limb dysfunction. Disability and rehabilitation, 35(4), 291-299. DOI: 10.3109/09638288.2012.691942

Morrison, V., Pollard, B., Johnston, M., \& MacWalter, R. (2005). Anxiety and depression 3 years following stroke: demographic, clinical, and psychological predictors. Journal of psychosomatic research, 59(4), 209-213. DOI: 10.1016/j.jpsychores.2005.02.019

Okada K., Kobayashi S., Yamagata S., Takahashi, K., Yamaguchi, S. 1997.Post stroke apathy and regional cerebral blood flow. Stroke, 28, 2437-2441. DOI: 10.1161/01.STR.28.12.2437 
Poynter, B., Hon, M. S., Diaz-Granados, N., Kapral, M., Grace, S. L., \& Stewart, D. E. (2009). Sex differences in the prevalence of post-stroke depression: a systematic review. Psychosomatics, 50(6), 563-569. DOI: 10.1176/appi.psy.50.6.563

Robinson-Smith, G., Johnston, M. V., \& Allen, J. (2000). Self-care self-efficacy, quality of life, and depression after stroke. Archives of physical medicine and rehabilitation, 81(4), 460-464. DOI: $10.1053 / \mathrm{mr} .2000 .3863$

Schultz, S. K., Castillo, C. S., Kosier, J. T., \& Robinson, R. G. (1997). Generalized anxiety and depression: Assessment over 2 years after stroke. American Journal of Geriatric Psychiatry, 5(3), 229-237. DOI: 10.1097/00019442-199700530-00007

Solgajová, A., Sollár, T., Vörösová, G., \& Zrubcová, D. (2017). Personality as significant predictor of post-stroke anxiety. Neuroendocrinology Letters, 38(4), 290-294.

Starkstein, S.E., Fedoroff, J.P., Price, T.R. , Leiguarda, \& R, Robinson, R.G . 1993. Apathy following cerebrovascular lesions. Stroke, 24, 1625-1630. DOI: 10.1161/01.STR.24.11.1625

Storor, D. L., \& Byrne, G. J. (2006). Pre-morbid personality and depression following stroke. International psychogeriatrics, 18(3), 457-469. DOI: 10.1017/S10416102 06003188

Taylor, G. H., Todman, J., \& Broomfield, N. M. (2011). Post-stroke emotional adjustment: A modified social cognitive transition model. Neuropsychological rehabilitation, 21(6), 808-824. DOI: 10.1080/09602011.2011.598403

Teoh, V., Sims, J., \& Milgrom, J. (2009). Psychosocial predictors of quality of life in a sample of community-dwelling stroke survivors: a longitudinal study. Topics in stroke rehabilitation, 16(2), 157-166. DOI: $10.1310 /$ tsr1602-157

Tielemans, N. S., Schepers, V. P., Visser-Meily, J. M., Post, M. W., \& Van Heugten, C. M. (2015). Associations of proactive coping and self-efficacy with psychosocial outcomes in individuals after stroke. Archives of physical medicine and rehabilitation, 96(8), 1484-1491. DOI: 10.1016/j.apmr.2015.04.009

Van Mierlo, M. L., Van Heugten, C. M., Post, M. W., De Kort, P. L., \& Visser-Meily, J. M. (2015). Psychological factors determine depressive symptomatology after stroke. Archives of physical medicine and rehabilitation, 96(6), 1064-1070. DOI: 10.1016/j.apmr.2015.01.022

Van Mierlo, M., Van Heugten, C. M., Post, M. W., Hoekstra, T., \& Visser-Meily, A. (2017). Trajectories of health-related quality of life after stroke: results from a one-year prospective cohort study. Disability and rehabilitation, 40(9), 997-1006. DOI: 10.1080/09638288.2017.1292320

Visser-Meily, J. A., Rhebergen, M. L., Rinkel, G. J., van Zandvoort, M. J., \& Post, M. W. (2009). Longterm health-related quality of life after aneurysmal subarachnoid hemorrhage: relationship with psychological symptoms and personality characteristics. Stroke, 40(4), 1526-1529. DOI: 10.1161/STROKEAHA.108. 531277

Yamagata S., Yamaguchi S., \& Kobayashi S. 2004. Impaired novelty processing inapathy after subcortical stroke. Stroke, 35, 1935-1940. DOI: 10.1161/01.STR.0000135017.51144.c9

\section{ACKNOWLEDGEMENTS:}

This study was supported by the research project VEGA 1/0418/19 Coping strategies in recovery after stroke. 